\title{
Management of Undescended Testis in Children in Aba Nigeria
}

\author{
Samuel Chidi Ekpemo ${ }^{1, *}$, Chukwuemeka Onyearugha ${ }^{2}$ \\ ${ }^{1}$ Department of Surgery, Abia State University, Aba, Nigeria \\ ${ }^{2}$ Department of Paediatrics, Abia State University, Aba, Nigeria
}

Email address:

chidisamuelekprmo@gmail.com (S. C. Ekpemo)

${ }^{*}$ Corresponding author

To cite this article:

Samuel Chidi Ekpemo, Chukwuemeka Onyearugha. Management of Undescended Testis in Children in Aba Nigeria. International Journal of Clinical Urology. Vol. 3, No. 1, 2019, pp. 15-17. doi: 10.11648/j.ijcu.20190301.14

Received: May 21, 2019; Accepted: July 3, 2019; Published: August 10, 2019

\begin{abstract}
Introduction: The anomalies of descent of the testes are common problem in newborn male infants. An absence of the testis in the scrotal sac is defined as cryptorchidism. Ectopic testis occurs when it migrates from its usual path of descent to lie in an unusual location. it affects $2-5 \%$ of the infants at birth and $1-2 \%$ of them at 3 months of age, the incidence is even higher in preterm infants, reported at $30 \%$. Methodology: This was a prospective cross-sectional study of all male children above 3 months of age with undescended testes who were managed by the Paediatric Surgery Unit of the Abia State University Teaching Hospital Aba from January 2016 to December 2018. Results: Thirty children aged $\leq 15$ years with 40 undescended testes managed in 3 years The age at surgery was fourteen months to 15 years (median six years); five (17\%) had correction before two years, $10(33 \%)$ before five years and $15(50 \%)$ at age $\geq 5$ years. Thirty $(75 \%)$ testes were palpable and ten $(25 \%)$ non-palpable. Evaluation was mainly clinical. Ultrasonography was performed for six non-palpable testes but was not helpful. Laparoscopy was not used in any patient. The condition was unilateral in twenty (67\%) and bilateral in ten (33\%). Forty per cent of the testes were in the inguinal canal, $25 \%$ at the external ring, and $15 \%$ each at the internal ring and abdomen respectively. Six (20\%) testes were macroscopically atrophic (canalicular three, abdominal two, internal ring one). Orchidopexy was performed for 34 undescended testes and orchidectomy forsix testes. Groin and scrotal haematoma developed following one orchidopexy. Following orchidopexy, two (6\%) testes retracted necessitating repeat surgery. Conclusion: There is a need to educate parents, traditional birth attendants, midwives and doctors in our sub-region to ensure earlier presentation and treatment.
\end{abstract}

Keywords: Undescended Testis, Children, Management

\section{Introduction}

Testicular maldescent is a common problem in newborn male infants. An absence of the testis in the scrotal sac is defined as cryptorchidism. The true undescended testis has arrested migration along its usual path of descent. [1] It is termed ectopic testis when it migrates from its usual path of descent to lie in an unusual location. The condition affects $2-$ $5 \%$ of the infants at birth and $1-2 \%$ of them at 3 months of age. The incidence is even higher in preterm infants, reported at $30 \%$. [2] Around $70 \%$ of undescended testes are palpable on clinical examination. Cryptorchidism occurs four times more commonly unilaterally than bilaterally. Most undescended testes migrate into the lower scrotum within the first 3 months of life, probably as a consequence of a postnatal surge of testosterone. Only in less than $1 \%$ of the cases does the testis remain persistently undescended by the age of 1 year. An atrophic or congenital absence of the testis may simulate a similar situation [3].

Testicular differentiation occurs during the 7 th week of gestation. The testis-determining factor is the SRY gene (sexdetermining region on Ychromosome). Hormones that control male sexual differentiation include testicular androgen from Leydig cells and Müllerian-inhibiting substance (MIS) from the Sertoli cell. Androgens (testosterone and dihydroxytestosterone) mediate the differentiation of paired wolffian ducts into seminal vesicles, 
epididymis, vas deferens, and ejaculatory ducts. MIS causes degeneration of the Möllerian structures. [4] The testis lies dormant in the abdomen until the 28th week of gestation; thereafter, it descends into the scrotum. The multifactorial mechanism of testicular descent involves: hormonal factors: the hypothalamus-pituitary-gonadal axis; the gubernaculum and genitofemoral nerve; increased abdominal pressure; and development/maturation of the epididymis. [5] Heyns et al. of South Africa have helped elucidate the role of the gubernaculum in testicular descent. [6] There is presently no unified theory of testicular maldescent. Anomalies of the above-mentioned normal mechanism have all been implicated in the development of cryptorchism.

It has implications for fertility in later life, as germ cell counts for patients with UDT remain normal during the first 6 months of life, but then reduce along with Leydig cell numbers. It is a risk factor for testicular cancer and is also associated with complications such as testicular torsion and inguinal hernias. In infants, correct localization of the testis is essential for surgical management, because the approach may vary with the location. In adults, however, it is still important to localize the testes and identify the complications. [7] In the setting of a unilateral UDT with an associated hypospadias, intersex should be considered and a karyotype would be indicated. Where bilateral impalpable UDTs are present, endocrine work-up is required. Elevated gonadotrophins, especially follicle-stimulating hormones (FSHs), likely represent bilateral anorchia. A human chorionic gonadotropin (HCG)-stimulation test has clinical use where gonadothrophins are normal. However, no matter what the results of the test, surgical exploration remains indicated. Typically, this involves injection of HCG (100 IU/kg or 2940 IU/body surface area) with a post testosterone level taken 72 hours after injection [8].

\section{Methodology}

A prospective study of all male children above 3 months of age with undescended testes managed by the Paediatric Surgery Unit of the Abia State University Teaching Hospital Aba from January 2016 to December 2018. A data proforma was designed to include demographic data including age at orchidopexy, clinical examination findings for the anatomical location of the testes, if in involves the right or left side, palpable or non palpable, preoperative investigations, findings at surgery involving the actual location of the testes and postoperative outcome. Statistical analysis was performed using statistical package for social sciences (version 17, SPSS Inc., Chicago, IL). A p value of $\leq 0.05$ was considered significant.

\section{Results}

Thirty children aged $\leq 15$ years with 40 undescended testes managed over four years period. The age at surgery was fourteen months to fifteen years (median six years).
Table 1. Age at orchidopexy.

\begin{tabular}{lll}
\hline Age & No patients & Percentage \\
\hline$<$ 2years & 5 & 17 \\
$<$ 5years & 10 & 33 \\
$>$ 5years & 15 & 50 \\
\hline
\end{tabular}

Five $(17 \%)$ had correction before two years, $10(33 \%)$ before five years and $15(50 \%)$ at age $\geq 5$ years. Thirty $(75 \%)$ testes were palpable and ten $(25 \%)$ non-palpable. Evaluation was mainly clinical. Ultrasonography was performed for three non-palpable testes but was not helpful. Laparoscopy was not used in any patient. The condition was unilateral in $22(73 \%)$ and bilateral in eight $(27 \%)$.

Table 2. Location of the testis at surgery.

\begin{tabular}{lll}
\hline location & number & percentage \\
\hline Inguinal & 18 & 45 \\
External ring & 19 & 25 \\
Internal ring & 6 & 15 \\
Abdomen & 6 & 15 \\
\hline
\end{tabular}

Forty-five per cent of the testes were in the inguinal canal, $25 \%$ at the external ring, and $15 \%$ each at the internal ring and abdomen respectively. Six (20\%) testes were macroscopically atrophic (canalicular three, abdominal two, internal ring one). Orchidopexy was performed for 34 undescended testes and orchidectomy six. Groin and scrotal haematoma developed following one orchidopexy. Following orchidopexy, two (6\%) testes retracted necessitating repeat surgery.

\section{Discussion}

The management of undescended testes remains a topical issue worldwide. In this sub- region like other developing countries most boys with the condition present much later than age of two years when significant irreversible pathogenic changes have occurred in the testes. [9] The median age at presentation in this study of 5.0 years which is equivalent to the median age reported from Zaria Northern Nigeria [10] and Benin Southern Nigeria [11] of 6.0 and 8.3 years respectively but higher than 3years reported in Lagos western Nigeria [12]. This suggests increased awareness among parents and other care-givers in Lagos and also reflects the better access to healthcare resulting in earlier presentation for surgery. However, $17 \%$ were operated before the recommended age of 2 years similar to $11 \%$ in Zaria, less than $25 \%$ of the patients in Lagos and $33.3 \%$ of patients in Nnewi (South Eastern Nigeria) [13]. This is not unrelated to the late presentation of patients due to paucity of knowledge of midwives and obstetricians, collaboration between the midwives and obstetricians, through advocacy will enhance detection at birth and early referral to paediatric surgeons.

The location of the impalpable testes frequently poses a challenge. $10(25 \%)$ testes were impalpable similar findings were earlier reported in Zaria (26\%) testes were impalpable. Ultrasonography gives false negative rates as high as $50 \%$ and is believed not to be any better than careful examination by an experienced surgeon [14]. Laparoscopy has become the gold 
standard in preoperative localization of non-palpable undescended testes [15-18]. However, the modality is not readily available in our setting. In our environment, only ultrasound is available and it did not locate the testis in any of the three patients who had it; operative exploration of the groin and retroperitoneal space is therefore performed in all our patients with impalpable testes using the extra peritoneal approach.

Surgery for undescended testis is indicated to increase the chances of fertility, to reduce the chances of malignant degeneration or at least increases the chances of early detection of malignancy, reduce the incidence of strangulation of associated hernias and also reduce the risk of torsion. Besides this it may also prevent psychological problems associated with an empty scrotum in later life [19].

The intra-operative location of the testes corresponded with previous studies where majority being within the inguinal canal and $20 \%$ being vanished atrophic. Majority benefited from a single-stage orchidopexy while 6 (15\%) required a staged treatment. Single-stage procedure was more likely in boys with palpable testes and those with testes located at the superficial inguinal ring. Single -stage procedure were also more likely in boys operated before age 3 years as previously reported by Osifo and co-workers in Benin Nigeria.

It has been shown that fertility after treatment for unilateral undescended testis is about $84 \%$, bilateral $60 \%$ and overall $79 \%$ [20]. That report noted that fertility is poor for bilateral undescended testis if treated after 18 years. About $10 \%$ of patients with testicular cancer may give a history of cryptorchidism [20]. In the present report, fertility and cancer rate cannot be ascertained. There is a need to conduct further studies on undescended testes in our environment and also improve the facilities available for evaluation.

\section{Conclusion}

Testicular maldescent is a common presentation in paediatric urology clinic worldwide. Laparoscopy has become the gold standard in preoperative localization of nonpalpable undescended testes. Late presentation in low and middle income countries, like Nigeria still persist despite increase in the number of tertiary hospitals. There is a need to educate parents, traditional birth attendants, midwives and doctors in our sub-region to ensure earlier presentation and treatment to prevent complications such as testicular torsion, cancer and infertility.

\section{References}

[1] Alexander Cho, Johanna Thomas, Ranil Parera Abraham Cherian, Undescended testis. BMJ 2019; 364: 1926.

[2] Kurz S, Tasian G Current management of undescended testes. Curr Treat option Peds. 2016, 2, 43-51.

[3] Niedzielski J Z, Oszukowska E, Słowikowska-Hilczer J. Undescended testis - current trends and guidelines: a review of the literature. Arch Med Sci 2016; 12, 3: 667-677.
[4] Radmayr C, Dogan NS, Hoebeke P. Management of undescended testis. Journal of paediatric urology 2016; 12, 335-343.

[5] Hirantha D. Peiris. Bhanumathi Lakshminarayanan, Osarumwense D. Management of undescended testes: a comparative study in England and Africa. Annals of Pediatric Surgery 2014, Vol 10 No 4.

[6] Heyns CF, Human HJ, Werely CJ, De Klerk DP. The glycosaminoglycans of the gubernaculum during testicular descent in the foetus. J Urol 1990; 143 (3): 612-61.

[7] Docimo SG, Silver RI, Cromie W. The undescended testicle: diagnosis and management. Am Fam Physician 2000; 62 (9): 2037-2044.

[8] Ayhan Abacı, Gönül Çatlı, Ahmet Anık, Ece Böber. Epidemiology, Classification and Management of Undescended Testes: Does Medication Have Value in its Treatment. J Clin Res Pediatr En docrinol 2013; 5 (2): 65-7.

[9] OKEKE AA, OSEGBE DN. Prevalence and characteristics of cryptorchidism in a Nigerian district. BJU International (2001), 88, $941 \pm 945$.

[10] Ameh EA, Mbibu HN. Management of undescended testes in children in Zaria, Nigeria. East Afr Med J 2000; 77: 485-487.

[11] Osifo DO, Osaigbovo EO. The prevalence, postnatal descent, and complications of undescended testes among children who underwent neonatal circumcision in Benin City, Nigeria. Journal of Paediatric Surgery 2009: 44 (4): 791-796.

[12] Adesanya OA, Ademuyiwa AO, Elebute OA, Ojewola R. The Undescended Testes in Children: a Prospective Epidemiological Study. East Cent. Afr. J. s urg 2013 Volume 18.

[13] Osuigwe AN, Nwose PC, Ndukwu C, Dilibe UC. Undescended Testis at Nnamdi Azikiwe Teaching Hospital, Nnewi, Nigeria - A Ten Year Audit. African Journal of Urology 2005; 11 (2): 101-104.

[14] Pankaj Nepal, Devendra Kumar, Vijayanadh Ojili Abnormal descent of the testis and its complications: A multimodality imaging review | Nepal | South African Journal of Radiology. Sajr2018 22: 1 .

[15] Cortes D., Thorup J. M., Lenz K., Beck B. L. and Nielsen O. H. Laparoscopy in 100 consecutive patients with 128 impalpable testes. Brit. J. Urol. 1995; 75: 281-287.

[16] Perovic S. and Janic N. Laparoscopy in the diagnosis of nonpalpable testes. Brit. J. Urol. 1994; 73: 310-313.

[17] Kiran Kumar, Vinay HG, Ramesh Reddy. Clinical Study and Role of Diagnostic Laparoscopy in the Management of Undescended Testis: Our Experience. J Surgery Volume $142-$ 2.

[18] Nassar A. H. M. Laparoscopic - assisted orchidopexy. a new approach to the impalpable testis. J. Paediat. Surg. 1995; 30: $39-4$.

[19] Kumar D., Bremner D. N. and Brown P. W. Fertility after orchidopexy for cryptorchidism: a new approach to assessment. Brit. J. Urol. 1993; 73: 516-520.

[20] Saw K. C, Eardley I, Dennis M. J. S. and Whitaker R. H. Surgical outcome of orchidopexy in previously unoperated testes. Brit. J. Urol. 1992; 70: 90-94. 